\title{
NOTAS PROGRAMÁTICAS PARA UMA NOVA HISTÓRIA DO PROCESSO DE CONSTITUCIONALIZAÇÃO BRASILEIRO*
}

\author{
PROGRAMMATIC REMARKS FOR A NEW HISTORY \\ OF BRAZILIAN CONSTITUTIONALIZING PROCESS
}

\author{
Marcelo Andrade Cattoni de Oliveira**
}

\begin{abstract}
RESUMO: O presente artigo tem por objetivo contribuir para uma reflexão acerca do sentido normativo que se autoexpressa na práxis de autodeterminação política no constitucionalismo, por meio de uma reconstrução acerca do modo como o processo de constitucionalização brasileiro articula memória e projeto, experiência e expectativa - e, assim, deixa entrever as suas relações com o tempo histórico. Apresenta a hipótese segundo a qual as relações que a constitucionalização brasileira desenvolve com o tempo histórico podem ser compreendidas como processo não linear e descontínuo, reconstruído como processo de lutas por reconhecimento e de aprendizagem social com o Direito, que se realiza ao longo da história, todavia sujeito a interrupções e a tropeços, mas que também é capaz de se autocorrigir. A justificação teórica entrecruza, de forma tensa e complexa, três marcos ou perspectivas fundamentais, a serem apenas esboçados aqui: 1 - Desconstrução, 2 - uma Filosofia Crítica da História atenta para
\end{abstract}

* Em sua versão original, o presente texto foi apresentado no II Congresso Internacional de História do Direito, para o painel "Direito como processo de aprendizagem de longa duração: revisão ou reconstrução (da história) e do direito", promovido pela Faculdade de Direito Milton Campos, Nova Lima - MG e organizado pela Associação Brasileira de Filosofia e Sociologia do Direito - ABRAFI. Ele foi redigido a partir do projeto de pesquisa "História e Teoria do Processo de Constitucionalização Brasileiro", coordenado por mim, junto ao Departamento de Direito Público da Faculdade de Direito da UFMG, que se desdobra atualmente em orientações de mestrado e de doutorado, assim como em três grupos de estudo e pesquisa, envolvendo pesquisadores da graduação e da pós-graduação. Agradeço ao colega Professor Lucas de Alvarenga Gontijo, Coordenador do II Congresso, pelo honroso convite. Naquela oportunidade, dediquei minha exposição a ele. Agradeço especialmente a David Francisco Lopes Gomes, mestrando pelo Programa de Pós-graduação em Direito, na linha de pesquisa Direito, Razão e História, e bolsista CAPES/REUNI junto ao Bacharelado em Ciências do Estado da Faculdade de Direito da UFMG, pelas importantes observações e sugestões. A minha referência originária e inesquecivel, para distinguir falta e ausência, é o poema Ausência, de Carlos Drummond de Andrade: "Por muito tempo achei que a ausência é falta./E lastimava, ignorante, a falta./Hoje não a lastimo./Não há falta na ausência./A ausência é um estar em mim./E sinto-a, branca, tão pegada, aconchegada nos meus braços,/que rio e danço e invento exclamações alegres,/porque a ausência, essa ausência assimilada,/ninguém a rouba mais de mim."

** Mestrado e Doutorado em Direito Constitucional (UFMG). Estágio pós-doutoral com bolsa da CAPES em Teoria e Filosofia do Direito (Università degli studi di Roma TRE). Professor Associado do Departamento de Direito Público e do Programa de Pós-graduação em Direito da Faculdade de Direito (UFMG). Coordenador pro tempore do Bacharelado em Ciências do Estado (UFMG). Membro do IDEJUST, do IHJ, da ABRAFI e do IBDP. 
os desafios postos pela Hermenêutica Crítica da Condição Histórica e 3 - Reconstrução. Com isso, pretende-se romper com perspectivas teóricas presentes na chamada "tradição dos retratos ou intérpretes do Brasil", da qual parcela significativa da doutrina constitucional brasileira faz parte, marcadas por uma leitura teológico política da falta de povo soberano, convergente quanto à proposta de uma modernização autoritária no marco de uma democracia possível e dualista da chamada brasilidade. Tal leitura tradicional contribui para a reificação da história constitucional brasileira ao impedir, com consequências deslegitimizantes, o reconhecimento de lutas da cidadania por direitos, que constituem internamente o processo político de aprendizado social com o Direito, de longa duração. Por fim, uma vez definidos os desafios para uma nova história do processo de constitucionalização brasileiro, propõe sete possíveis eixos de pesquisa.

PALAVRAS-CHAVE: Desconstrução. Hermenêutica Crítica. Reconstrução. Retratos do Brasil - processo de constitucionalização.

ABSTRACT: This article aims to contribute to a reflection on the normative sense that expresses itself in the praxis of political self-determination in constitutionalism through a reconstructive approch about how the Brazilian process of constitutional-making articulates memory and project, experience and expectation - and, thus, suggests its relationship with historical time. Presents the hypothesis that the relationship between Brazilian constitutional-making and historical time can be understood as a process that is not linear and discontinuous, reconstruct as a process of struggles for recognition and social learning with the law, which takes place throughout history, however subject to interruptions and setbacks, but is also able to correct itself. The theoretical justification intersects, in a tense and complex sense, three fundamental perspectives or frameworks, to be only outlined here: 1 - Deconstruction, 2 - a Critical Philosophy of History's attention to the challenges posed by Critical Hermeneutics of historical condition and 3 - Reconstruction. With this, it aims to break with theoretical perspectives present in the "tradition of pictures or interpreters of Brazil" in which a significant portion of Brazilian constitutional doctrine is a part, marked by a theological reading of the lack of political sovereign people, converged on the proposal an authoritarian modernization within the framework of a possible democracy and the dualistic reading of the called Brazilianness. This traditional reading contributes to the reification of the Brazilian constitutional history to prevent, with consequences deslegitimizantes, recognition of the struggles for citizenship rights, which are inside the political process of social learning with the law, long-lasting. Finally, once defined the challenges for a new history of Brazilian process of constitutionalmaking, it proposes seven possible lines of research.

KEYWORDS: Desconstruction. Critical hermeneutics. Reconstruction. Pictures of Brazil. Constitutionalmaking process. 
"Meu tempo é quando" - Vinicius de Moraes.

\section{INTRODUÇÃ̃O}

O presente artigo tem por objetivo contribuir para uma reflexão acerca do sentido normativo que se autoexpressa na práxis de autodeterminação política no constitucionalismo, por meio de uma reconstrução acerca do modo como o processo de constitucionalização brasileiro articula memória e projeto, experiência e expectativa - e, assim, deixa entrever as suas relações com o tempo histórico. Avança a hipótese segundo a qual as relações que a constitucionalização brasileira desenvolve com o tempo histórico podem ser compreendidas como processo não linear e descontínuo, reconstruído como processo de lutas por reconhecimento e de aprendizagem social com o Direito, que se realiza ao longo da história, todavia sujeito a interrupções e a tropeços, mas que também é capaz de se autocorrigir. A justificação e os marcos teóricos a serem desenvolvidos visam romper com perspectivas teóricas presentes na chamada "tradição dos retratos ou intérpretes do Brasil", da qual parcela significativa da doutrina constitucional brasileira faz parte, marcadas por uma leitura teológico política da falta de povo soberano, convergente quanto à proposta de uma modernização autoritária no marco de uma democracia possível e dualista da chamada brasilidade. Tal leitura tradicional contribui para a reificação da história constitucional brasileira ao impedir, com consequências deslegitimizantes, o reconhecimento de lutas da cidadania por direitos, que constituem internamente o processo político de aprendizado social com o Direito, de longa duração (BRAUDEL, 2005, p. 41-78). Por fim, uma vez definidos os desafios para uma nova história do processo de constitucionalização brasileiro, propõe sete possíveis eixos de pesquisa.

\section{JUSTIFICAÇÃO TEÓRICA}

A justificação teórica entrecruza, de forma tensa e complexa, três marcos ou perspectivas fundamentais, a serem apenas esboçados aqui: 2.1 - Desconstrução, 2.2 Uma Filosofia Crítica da História atenta para os desafios postos pela Hermenêutica Crítica da Condição Histórica e 2.3 - Reconstrução.

2.1 - Desconstrução: "escovar a contrapelo" (BENJAMIN, 1995) a chamada tradição dos intérpretes e dos retratos do Brasil, da qual faz parte "a doutrina constitucional brasileira".

A desconstrução, no sentido de Derrida, consiste na realização complexa de quatro operações interventivas, visando desmontar, desmantelar, desestabilizar ou subverter uma determinada construção teórica, o modo com que ideias, crenças e valores são estruturados e se sustentam mutuamente, dentro de um dado esquema conceitual. A razão pela qual se pretende intervir nos esquemas conceituais desconstruindo-os 
consiste na exigência do reconhecimento e da explicitação de tudo aquilo que não possa ser reduzido a certos pares irredutíveis de conceitos opostos, e que, portanto, acaba sendo excluído e marginalizado, assim como reconhecer a hierarquia imposta que estrutura esses pares conceituais: universal/particular, espiritual/material, eterno/ temporal, homem/mulher, humano/animal, público/privado, real/ideal, fatos/normas etc. Primeiramente, busca-se a identificação das construções conceituais a partir das quais se pretende descrever uma realidade, comumente construída com a utilização de um ou mais pares de conceitos considerados, para determinado campo teórico, como irredutíveis. Em um segundo momento, a explicitação das hierarquias subjacentes a essa descrição dualista. Terceiro, a subversão dessa hierarquia, procurando mostrar que uma dada ordenação reflete certas opções estratégicas e não algo que possa ser considerado inerente ou natural a esses pares conceituais. Por fim, a produção de um terceiro termo complicador que, em última análise, juntamente com a operação de subversão, leva a uma deformação, a uma reformulação ou mesmo a uma transformação. (BORRADORI, 2003, p. 197-199; PERELLI in ORTIZ-OSÉS e LANCEROS, p. 143-149; DERRIDA IN CORNELL, 1992, p. 3-67; DERRIDA e ROUDINESCO, 2004, p. 9-31).

Nesse sentido, o que se pretende é “escovar a contrapelo" (BENJAMIN, 1995) a chamada tradição dos intérpretes e dos retratos do Brasil, da qual faz parte "a doutrina constitucional brasileira", procurando explicitar e subverter os seus pressupostos não problematizados.

Leituras tradicionais da história brasileira são feitas no espelho de uma teologia política segundo a qual somente por meio da "ruptura institucional" ou "revolucionária", promovida pelo macrossujeito "povo soberano", poder-se-ia caracterizar o genuíno exercício de um poder constituinte capaz de legitimar uma ordem constitucional, desde a sua origem - algo no que, aliás, parecem convergir, quer sejam conservadores, quer progressistas, importantes autores da chamada "tradição dos retratos do Brasil" (PACE BARACHO JUNIOR, 2009, p. 158-166).

Há de se considerar - estando atento aos motivos, propícios e inibidores, para uma história da mentira (em que inverdade é diferente de mentir. Cf. DERRIDA, 1996, p. 32-35; 2006, p. 88-101) - que pontos de vista comuns aproximam autores tão supostamente diferentes entre si, tais como Oliveira Vianna (2005, p. 347-408) e Sérgio Buarque de Holanda (1995, p. 139-188): o darwinismo de um e o historicismo de outro não deixam de convergir numa narrativa que é sempre contada, ritualizada, da perspectiva do vencedor (BENJAMIN, 1995). Ou seja, da perspectiva das chamadas "elites" sociais, econômicas e políticas; perspectiva essa que não apenas despreza a visão dos oprimidos, mas fecha os olhos para as lutas políticas por direitos e pelo reconhecimento da cidadania, que não podem ser reduzidos a meras concessões paternalistas. E dessa tão supostamente esquecida, quanto louvada, "tradição do pensamento brasileiro" (cf. REIS, 2006a e 2006b; CÂNDIDO in HOLANDA, 1995; PAIM in VIANNA, 2005; SOUZA, 2009) também 
não deixam de participar autores como Gilberto Freyre (1998), Caio Prado Junior (1969), Raymundo Faoro (FAORO, 2001, p. 865-887), Roberto da Matta $(1981,1999)$ e José Murilo de Carvalho (1990; 1998; 2001). Em tal contexto, cabe salientar a existência de uma tradição que se faz representar pelo chamado discurso do mesmo, em termos de diagnóstico e de solução possível para o Brasil. Primeiro, o diagnóstico: "nunca ou poucas vezes teriam acontecido rupturas genuínas na história política do País". Em segundo, a seguinte e inevitável consequência a que esse diagnóstico convergente poderia levar a uma solução negociada e de "centro", entre as elites, e todavia reificante, como "esquecimento e negação, não reconhecimento" (HONNETH, 2007a, p. 51-62) da cidadania: na falta de rupturas revolucionárias, a denunciar a própria falta de povo ou nação que pudesse ser o sujeito, titular, de um genuíno poder constituinte, a única via que permaneceria aberta seria a da "modernização autoritária" ou do "autoritarismo instrumental" (cf. SANTOS, 1978), no contexto de uma democracia possível (pelo e para o "povo", mas não do "povo"), a ser conduzida pela "máscara totêmica" (KELSEN, 2000, p. 303-343) de um "suposto substituto funcional" (NEUMANN, 1957, p. 22-68; 1996, p. 101-141) do velho Poder Moderador imperial, na figura secularizada (SCHMITT, 1988, p. 46), seja a de um presidente forte, a das forças armadas, ou até mesmo, mais recentemente, a de uma corte constitucional. Este "substituto-mascarado" - que paradoxalmente pudesse ser escolhido/erigido pela elite política esclarecida, consciente e responsável, e que, assim, a representasse - seria ao mesmo tempo capaz de salvaguardar e de ocupar o lugar vazio da cidadania e da nacionalidade inexistentes, a fim de forjá-las e para governá-las...

Em obra recente, Jessé Souza (2009) chama atenção acertadamente para o caráter racista e conservador dessa tradição de pensamento, ao comparar, por um lado, o pensamento de Gilberto Freyre, glorificador da herança luso-brasileira e de uma identidade nacional mestiça, e, de outro, o pensamento (pseudo) crítico de autores como Sérgio Buarque de Holanda, Raymundo Faoro, Simon Schwartzman e Roberto da Matta, defensores da tese segundo a qual "o brasileiro" sofreria de um "mal de origem", ou seja, a mesma herança, agora valorada de modo invertido, como patrimonialista e personalista, que nos teria sido legada pelos portugueses (SOUZA, 2009, p. 56). Segundo Souza, Buarque de Holanda inverte especularmente a leitura "positiva" de Freyre, todavia sem questionar-lhe os fundamentos racistas (SOUZA, 2009, p. 54), ou seja, dá continuidade a uma espécie de "teoria emocional da ação social", combinada a uma visão economicista de mundo, que insiste num suposto caráter pré-moderno da sociedade brasileira, com todas as suas "compensações fantasiosas" (SOUZA, 2009, p. 58): o brasileiro é "cordial”, "caloroso", "hospitaleiro", "sensual”, "exótico", "edênico". Para Souza:

"A visão que aceita a tese de nosso mal de origem possui apenas um 'charminho crítico" superficial, porque, na verdade, aceita o 'racismo disfarçado' do culturalismo como verdadeiro. Desse modo, o preconceito do senso comum, ou seja, o preconceito do 'exotismo' construído 
pelo domínio pré-moderno da emoção e da sentimentalidade como representação de sociedades inteiras se torna, também, o preconceito que entra de contrabando na reflexão metódica, ou seja, do conhecimento produzido com prestígio e a autoridade da ciência. Essa é a gênese verdadeira da interpretação 'científica' até hoje dominante entre nós não só nas universidades, mas também fora delas, na imprensa e no debate público.” (SOUZA, p. 57)

Segundo Jessé Souza (2009, p. 54-72), sobretudo a partir de Sérgio Buarque de Holanda, o que caracterizaria a chamada "brasilidade" seria a sua plasticidade (conceito apropriado de Gilberto Freyre), tida como nossa herança ibérica, conceito fundamental para a construção das teses do patrimonialismo, do personalismo, do "homem cordial", do estamento, da "malandragem", do "jeitinho brasileiro" etc., que irão permear as leituras (pseudo) críticas posteriores, criadoras verdadeiramente de toda uma mitologia culturalista da brasilidade (o mito do mercado virtuoso confundido com a sociedade e o mito do Estado corrupto, por natureza, sem falar no mito do pioneirismo bandeirante e no mito de São Paulo como a "Massachussets tropical", em contraposição ao Brasil "tradicional" e "arcaico" etc., ou seja, "o resto"). Tal mitologia culturalista - que "generaliza um preconceito arraigado do senso comum e o continua com o beneplácito da 'autoridade científica" (SOUZA, 2009, p. 79) - é extremamente atuante, como imaginário social historicamente "reproduzido todo dia nas famílias por pessoas que amamos, e na escola e nas universidades, por pessoas que respeitamos, a sua reprodução se torna automática e não refletida" (SOUZA, 2009, p. 71). E isso de tal modo a justificar ideologicamente desigualdades e privilégios estruturais, todavia não naturais (SOUZA, 2009, p. 71).

Não se pode mais pensar em todo esse "patrimônio cultural" e suas origens - não tanto "a fadiga dos grandes gênios que o criaram, mas antes a escravidão sem nome de seus contemporâneos" - "sem sentir horror": "Não existe documento da cultura sem que seja, ao mesmo tempo, documento da barbárie" (BENJAMIN, 1995, p. 79). Longe de assumir a mera perspectiva piedosa ou de compaixão em prol das vítimas e dos oprimidos idealizados, típica de uma retórica fácil e ruim, do chamado "politicamente correto" (SOUZA, 2009, p. 89-100), o que está em questão é o difícil e insaturável caminho da construção pública da justiça como possibilidade de toda desconstrução (DERRIDA in CORNELL, 1992). É, portanto, chegada a hora, e a hora do presente é a do juízo, de seguir a recomendação de Benjamin e assumir como nossa a tarefa de "escovar a contrapelo a história" (BENJAMIN, 1995, p. 78-79; BENJAMIN, 2006, p. 483-517; cf. MARRAMAO, 2000, p. 311-329, 2008a, p. 108-130; COSTA, 2008, p. 143-214).

Afinal, como se pode considerar a legitimidade de um processo de constitucionalização senão como sendo a própria construção, aqui e agora, dessa legitimidade por-vir? (DERRIDA, 2003; 2004) E de uma legitimidade por meio da legalidade, do reconhecimento segundo o qual se deve, inclusive, rever a teologia política atribuída à concepção francesa do poder constituinte como ato do soberano (MARRAMAO, 
2003, p. 225-232) e compreender que, hoje, após mais de dois séculos de constitucionalismo, o poder constituinte "requer mais do que a simples e bruta tomada do poder ou manipulações palacianas para obter apoio do povo."? (CARVALHO NETTO 2002, p. 45). Nesse sentido, para Menelick de Carvalho Netto, o poder constituinte, embora ilimitado em relação à ordem com a qual rompe,

“(...) encontra-se vinculado a criar instituições capazes de garantir esses princípios [liberdade e igualdade] jurídica e politicamente, pois, ao institucionalizar o poder público, o faz de tal modo que a própria constituição dos órgãos e a forma de atuação dos mesmos os densifique. O Estado moderno retira de seu próprio operar, de seu funcionamento regido por esses mesmos princípios, o substrato de legitimidade necessário à sua reprodução cotidiana" (CARVALHO NETTO, 2002, p. 41-42).

E é assim que Habermas (2001), ao reconstruir a pergunta pressuposta a um processo constituinte legítimo - acerca de quais direitos devemos atribuir-nos, reciprocamente, caso queiramos regular legitimamente nossa convivência por meio do Direito -, afirma que numa leitura que leva a sério a relação interna entre Direito e democracia, bem como a relação de complementaridade entre Direito e moral, a forma jurídica moderna, justificada normativamente com base no princípio do discurso como princípio democrático, não se encontra à disposição da autolegislação democrática, visto que a constituiu internamente. Na modernidade, o poder constituinte legítimo só se expressa mediante o medium do Direito moderno. Nesse sentido, Habermas afirma:

"Ao invés de apoiar-me num realismo moral, que tem poucas chances de ser defendido, sugiro que entendamos o próprio regresso [ao infinito] como a expressão compreensível de um aspecto do caráter da constituição dos Estados democráticos de direito, isto é, a sua abertura para o futuro: uma constituição que é democrática, não somente de acordo com seu conteúdo, mas também de acordo com a fonte de sua legitimação, constitui um projeto capaz de formar tradições com um início marcado na história. Todas as gerações posteriores enfrentarão a tarefa de atualizar a substância normativa inesgotável do sistema de direitos estatuído no documento da constituição (...) É verdade que essa continuação falível do evento fundador só pode escapar do círculo da autoconstituição discursiva de uma comunidade, se esse processo, que não é imune a interrupções e a recaídas históricas, puder ser interpretado, a longo prazo, como um processo de aprendizagem que se corrige a si mesmo" (2001, p. 768).

Ou seja, a relação interna entre Estado de Direito e democracia, direitos humanos e soberania popular, realiza-se, na dimensão do tempo histórico, como um processo de aprendizagem social com o Direito, que é sujeito a tropeços, mas é capaz de corrigir a si mesmo, se compreendermos a Constituição como projeto que transforma o ato fundador num processo constituinte que tem continuidade por meio de sucessivas gerações.

Contudo, proponho uma modificação desse argumento desenvolvido por Habermas em resposta às críticas de Michelman, no que se refere ao modo de se compreender o problema do regresso ao infinito e a questão do fundamento do Estado Democrático de Direito. $\mathrm{O}$ primeiro aspecto diz respeito ao modo de exposição da tese da relação interna 
entre Estado de Direito e democracia. A questão central é o agravamento do chamado "déficit histórico e sociológico" na abordagem de temas normativos, apresentados pela teoria do agir comunicativo, como Honneth chama atenção desde a década de 80 do século passado (2002a, 2002b, 2006, 2007b). Cabe aqui sublinhar que Habermas insiste em se utilizar da linguagem do contratualismo e prefere simular um "experimento de pensamento", ao invés de radicalizar o enfoque reconstrutivo que sua própria teoria propõe, o que lhe permitiria situar historicamente as exigências normativas que se impuseram ao longo do processo de modernização. Já o segundo aspecto remete ao modo de compreensão do chamado deslocamento temporal do fundamento do direito, do passado para o futuro, em razão do caráter de abertura ao futuro das constituições democráticas (HABERMAS, 2001). Essa tese exige maiores precisões: a questão que o tempo presente nos coloca ao pensamento não é propriamente a do deslocamento temporal, puro e simples, do passado ao futuro (Cf. LUHMANN, 1990). É preciso estar atento quanto ao modo e ao grau dessa abertura ao futuro (MARRAMAO, 2005b, p. 83). O Direito não terá um "fundamento" no futuro se não tiver no presente e se o presente também não se abrir ao passado como seu futuro, aprendendo a lidar com o risco de perda do espaço de experiência - como no caso do Direito, com o risco permanente da perda da memória dos percursos e das lutas por reconhecimento de direitos ao longo da história (cf. RICOEUR, 2000, 2007; e HONNETH, 2002, 2006, 2007). Corremos o risco de viver, recorrentemente, como chama atenção Marramao (2008a, p. 95-107), a síndrome da pressa, ou seja, a de um futuro passado, a redução do espaço de experiência, a hipertrofia do horizonte de expectativa, enfim, o não aprendizado com uma experiência intercompartilhada. Aqui, o tema da reificação, em Honneth (2007, p. 63), "como esquecimento do reconhecimento", pode ser enriquecido com a reflexão de Marramao (2005b, p. 73-106) sobre os temas do tempo cairológico - do tempo oportuno ou devido e da síndrome da pressa - ou do futuro passado -, por meio de instigantes inter-relações (cf. MARRAMAO, 2008a, p. 33-36). E é assim que se deve, pois, perguntar, com Derrida e Roudinesco, inspirados em Victor Hugo: "qual amanhã?" (2004).

Como bem lembrava Arendt, os revolucionários franceses e norte-americanos de fins do século XVIII procuraram lidar de modo distinto com a questão acerca da "necessidade de um absoluto", que em ambos os lados do Atlântico teria surgido no curso das revoluções, uma vez que nem os norte-americanos, nem os franceses poderiam justificar, respectivamente, quer na tradicional Constituição britânica, quer no tradicional direito francês anterior ao período do Absolutismo, as rupturas jurídico-políticas que estavam empreendendo. Isto porque, do ponto de vista do direito tradicional, tanto uma declaração de independência e o não reconhecimento da autoridade da Coroa britânica quanto uma retirada do Terceiro Estado da Assembleia dos Estados Gerais seriam "atos inconstitucionais"; e, assim, também as deliberações que a partir dali fossem tomadas (1990, p.156-171). 
Segundo Arendt, para solucionar o problema deste "círculo vicioso", que poderia levar à falta de um fundamento capaz de justificar suas ações, é que Sieyes teria construído a concepção do poder constituinte distinto dos poderes constituídos, bem como atribuído a origem comum do poder e da autoridade à Nação soberana, encarnada pelo Terceiro Estado e, mais tarde, pela Assembleia Nacional Constituinte, pelas convenções que a sucederam, assim como por todos que, como Bonaparte, se autoproclamaram delegados desse "soberano" (1990, p. 156-171). Por outro lado, já a "solução norte-americana" teria envolvido, justamente, a atribuição de um duplo sentido ao ato jurídico-político de constituição dos Estados Unidos da América: a Constituição norte-americana, como "ato de fundação", teria ao mesmo tempo o sentido de um principium, ou seja, de princípio, e de preceito, de começo e de norma que se autoexpressa no próprio começar (beginning). Assim, segundo Arendt:

\footnotetext{
"O que salva o ato de [começar] de sua própria arbitrariedade é que ele traz dentro de si mesmo a sua própria norma, ou, mais precisamente, que o princípio e a norma, o principium e o preceito, além de se relacionarem um com o outro, são também contemporâneos. $\mathrm{O}$ absoluto, do qual o começo deve derivar sua própria validade e que deve salvá-lo de sua inerente arbitrariedade, é a norma, que aparece no mundo ao mesmo tempo que o começo. $\mathrm{O}$ modo pelo qual o iniciador principia o que quer que pretenda fazer determina a lei da ação a ser observada por todos os que a ele se unirem, para partilhar de seu empreendimento e levá-lo à concretização. A norma, como tal, inspira as ações que haverão de se seguir e permanece atuante durante todo o tempo em que essas ações perdurarem" (1990, p. 170).
}

A partir desse ato de começar, que traz dentro de si mesmo seu preceito - ou sentido normativo que se autoexpressa na práxis de autodeterminação política -, o povo (the People, que em inglês é uma palavra no plural) se autoconstituiria como um novo corpo jurídico-político, autoconstituído de forma plural por cidadãos que, no exercício de sua autonomia política, assumiriam o compromisso, a mútua promessa, de reciprocamente reconhecerem-se iguais direitos de liberdade. Promessa mútua, essa, que teria criado laços com o futuro, sendo, pois, renovável e alargada, a cada decisão judicial, que possuiria a autoridade para reinterpretá-la, ou a cada emenda constitucional, que viria a desenvolvê-la, resgatando, assim, o sentido normativo que se teria autoexpressado no processo constituinte de elaboração e de ratificação do texto constitucional. Assim, para a compreensão do sentido normativo inerente ao próprio ato de fundação, nos termos em que Arendt o concebe, é fundamental, aqui, o conceito de "promessa" (ARENDT, 1958, p. 243 e seguintes; CALVET de MAGALHÃES, 2007), assim como a sua importância:

\footnotetext{
"Nesse sentido, o curso da Revolução Americana nos mostra um exemplo inesquecível e nos ensina uma lição sem precedentes; pois essa revolução não eclodiu simplesmente, mas foi antes conduzida por homens que tomaram juntos uma resolução, unidos pela força de compromissos mútuos. O princípio veio à luz durante os conturbados anos em que foram
} 
lançadas as fundações - não por determinação de um arquiteto, mas pelo poder combinado de muitos - foi o princípio interconexo da promessa mútua e da deliberação comum" (ARENDT, 1990, p. 170).

Desse modo, é possível resgatar um importante "tesouro" para a teoria constitucional contemporânea, a partir das reflexões de Arendt sobre as revoluções do século XVIII: o constitucionalismo democrático não possui necessariamente uma legitimidade vivida como falta de um fundamento último, como uma espécie de nostalgia desse fundamento, como dor e obsessão da perda de fundamento último, soberano (MARRAMAO, 2000, p. 311-329), enfim, como se um fundamento último fizesse falta ao constitucionalismo democrático. O fundamento último e soberano não faz falta. Ao contrário, o constitucionalismo democrático lança-se, pois, aqui e agora, a um por-vir, a um futuro-em-aberto, como projeto falível, mas no sentido de que o presente pode ser o futuro de um passado que agora é redimido pelo agir político-jurídico, constitucional, que o constitui. Essa abertura remete à própria questão da legitimidade vivida como vazio, não mais passível de ser preenchido, e como ausência assimilada - e não como falta - de fundamento último, ao processo jurídico-político de construção da legitimidade por meio da realização no tempo histórico da relação interna entre as noções de autogoverno e de iguais direitos individuais de liberdade, concretizadores de uma noção complexa de autonomia. E somente assim se pode, portanto, afirmar que as exigências normativas, que se colocam a esse processo constituinte, ao invés de barreiras a ele, são, na verdade, constitutivos dele: elas são uma forma de explicitação ou de autoexpressão da própria noção complexa de autonomia que lhe é subjacente (HABERMAS, 2001, p. 171).

Nesses termos, nossas hipóteses desconstrutivas podem ser formuladas, então, da seguinte forma:

2.1.1) uma teologia política da falta (seja do imperador exilado; da nacionalidade não forjada; e do povo soberano), num diálogo com Benjamin, Derrida e Marramao;

2.1.2) a convergência entre conservadores e progressistas quanto ao diagnóstico da falta de povo e quanto à proposta de uma modernização autoritária ou a um "autoritarismo instrumental" (SANTOS, 1978) como meio para se forjar a nacionalidade.

2.2 - Uma Filosofia Crítica da História atenta para os desafios postos pela Hermenêutica Crítica da Condição Histórica. Chaves hermenêuticas de releitura da história: "historicidade"; "espaço de experiência e horizonte de expectativa"; "lutas por reconhecimento"; "aprendizagem"; "narratividade"; "secularização".

Por um lado, podemos afirmar com Koselleck que: 
"Os conceitos decerto incluem conteúdos políticos e sociais, mas a sua função semântica, o seu desempenho, não é dedutível (ableitbar) somente dos dados sociais e políticos aos quais se referem. Um conceito não é só um indicador, mas também um fator das conexões por eles compreendidas." (2006, p.109)

Ou seja, um conceito tem também a capacidade de "produzir relações, de modelar e orientar os próprios referenciais sócio-políticos" (KOSELLECK, 2006, p.109. 110; MARRAMAO, 1995, p. 80; PAIXÃO e BARBOSA, in PEREIRA e DIAS, 2008, p. 128-129).

E, por outro lado, queremos destacar com Arendt que:

"[s]e é verdade que todo pensamento se inicia com a lembrança, não é menos correto que nenhuma memória perdura e permanece intacta, a menos que seja condensada e inserida num conjunto de noções conceituais, dentro do qual ela possa afirmar-se cada vez mais. As experiências e as narrativas que brotam de tudo aquilo que os homens fazem e atravessam, dos acontecimentos e ocorrências, se dissipam na inanidade inerente à palavra viva e aos feitos vivos, a menos que sejam discutidos e comentados vezes sem conta. O que salva as ações dos homens de sua inerente inutilidade não é outra coisa senão essa discussão incessante que se trava em torno delas, a qual, por sua vez, permanece inútil a não ser que dê origem a certas concepções e a determinados marcos dominantes que favoreçam a futura evocação ou que simplesmente lhe sirvam de referência" (ARENDT, 1990, p. 176).

Uma filosofia crítica da historia, desenvolvida num contexto pós-hegeliano e construída a partir da história dos conceitos, propõe, num primeiro momento em que a ação investigativa em História se processe pela análise sincrônica do passado que, ao ser redefinida, é completada de forma diacrônica. E, num segundo momento, propõe que os conceitos não sejam reduzidos a um contexto situacional único: os sentidos lexicais devem ser investigados ao longo de uma sequência temporal, a fim de serem ordenados uns em relação com os outros, de tal modo que as análises de cada sentido possa agregarse a uma história do conceito. Nesses termos, por meio da história dos conceitos podese perceber por quanto tempo permaneceu inalterado o sentido de um conceito, assim como o quanto este foi alterado, ao longo do tempo. Assim, é com base na análise diacrônica do uso de um conceito que se poderia, inclusive, avaliar seu impacto social ou político.

Os marcos para uma filosofia crítica da história são os seguintes:

2.2.1) "Espaço de experiência e horizonte de expectativa" como categorias do tempo histórico (KOSELLECK, 2006, p. 305-327);

Embora para Koselleck não se possa pressupor um sentido imanente à história, isso não significa que não se possa atribuir ou mesmo reconhecer sentido a ela. Para a compreensão da especificidade do tempo histórico, Koselleck utiliza duas categorias metahistóricas que, em última análise, poderiam justificar-se numa certa antropologia filosófica de matriz pós-metafísica: 1 - espaço de experiência e 2 - horizonte de expectativa. 
A experiência é o passado atual, aquele no qual acontecimentos foram incorporados e podem ser lembrados, em que se fundem tanto elaboração racional como formas inconscientes de comportamento. Já a expectativa é o futuro presente. A expectativa pode ser composta por desejo, vontade, medo, esperança, curiosidade, análise racional etc. (KOSELLECK, 2006, p.310).

Experiência e expectativa não são termos complementares, apesar de se relacionarem. Todavia, jamais coincidem, de tal modo que uma expectativa jamais pode ser deduzida exclusivamente da experiência. Assim, as expectativas podem ser revistas, já as experiências, recolhidas. Como afirma Koselleck, "uma experiência feita, está completa na medida em que suas causas são passadas, ao passo que a experiência futura, antecipada como expectativa, se decompõe em uma infinidade de momentos temporais" (2006, p. 310).

2.2.2) Os conceitos de reconhecimento recíproco e aprendizagem histórico no contexto da discussão contemporânea em torno de uma reatualização direta ou indireta do sistema hegeliano (Cf. HONNETH, 2007b; WILLIAMS, 1997; PIPPER, 2008; PEPERZAK, 2001; GADAMER e KOSELLECK, 1997; LABARRIÈRE e JARCZIK, 1989; BOURGEOIS, 2003, 2004; KERVÉGAN, 2007; RICOEUR, 2000);

Embora não se possa aprofundar aqui o rico debate acerca de uma reatualização direta - que busca reinterpretar de forma sistemática o pensamento de Hegel, levando a sério a sua Ciência da Lógica - ou de uma reatualização indireta - que pretende romper seja com a ontologia hegeliana, seja com a sua visão orgânica de constituição, seja com sua filosofia da historia -, cabe considerar as estruturas de reconhecimento recíproco como próprias a formas de vida racionais.

Segundo Habermas:

“(a)s relações concretas de reconhecimento, que uma ordem jurídica legitima não faz senão certificar, provêm sempre de uma luta por reconhecimento; esta luta vem motivada pelo sofrimento que foi produzido pelo desapreço concreto de que alguém é objeto e pela rebelião contra esse desapreço (Honneth). São, como mostrou Axel Honneth, experiências de humilhação da dignidade humana que devem ser articuladas para verificar os aspectos sob os quais no contexto concreto os iguais devem ser tratados de forma igual e os desiguais de forma desigual. Essa disputa [pública] em torno da interpretação de necessidades não podem ser delegadas nem aos juízes, nem aos administradores, nem sequer aos legisladores." (HABERMAS, 1998, p. 511)

Nesse prisma, uma mudança paradigmática do sentido normativo dos direitos fundamentais, como princípios insaturáveis e interpretáveis de modo construtivo, se dá publicamente por meio de uma luta por reconhecimento de novos sujeitos de direitos. São lutas por reconhecimento que colocam em questão compreensões paradigmáticas 
em disputa acerca do Direito e, assim, podem mobilizar a opinião pública e protestar diante de situações de discriminação e de exclusão, visando não apenas influenciar o processo de tomada de decisões, mas também dele legitimamente participar.

2.2.3) A discussão sobre aprendizagem e narratividade históricas (DWORKIN, 1986; RICOEUR, 2000; HABERMAS, 2001);

Neste ponto, caberia retomar, em especial, para além das contribuições de Ricoeur ou de Habermas, a tese do Direito como Integridade, de Ronald Dworkin (1986). Segundo o jurista norte-americano, o Direito constitui a melhor justificação do conjunto das práticas jurídicas, a narrativa que faz de tais práticas as melhores possíveis. A chamada metáfora do romance em cadeia (chain novel), introduzida por Dworkin a partir da década de 1980, para sustentar a sua famosa tese da resposta correta, tanto em contraposição ao positivismo jurídico quanto ao realismo jurídico, ilustra exatamente todo um processo de aprendizado social subjacente ao Direito compreendido como prática social interpretativa e argumentativa, um processo intergeracional, sujeito a tropeços, mas capaz de corrigir a si mesmo. Assim, o Direito é visto por Dworkin (1985) como um empreendimento público, que se dá ao longo de uma história institucional, reconstruída de forma reflexiva à luz dos princípios jurídicos de moralidade política, que dão sentido a essa história.

2.2.4) A reconstrução do conceito de secularização (Cf. acepções, MARRAMAO, 1994) e da crítica à noção em Habermas de "sociedade pós-secular" (Cf. MARRAMAO, 2008).

Na obra La passione del presente (2008, p. 214-221), Giacomo Marramao faz duas observações cruciais em relação à obra recente de Habermas, sobretudo a partir do ensaio Fé e Ciência, que vale a pena considerar: a primeira é a de que Habermas teria revisto sua compreensão da secularização, retomando o conceito jurídico-político de separação entre Estado e Igreja, ou seja, secularização não é necessariamente sinônimo de dessacralização e desencantamento das visões de mundo (Weber), visto que tal separação implica uma autonomia não apenas do Estado, unilateralmente, mas também das igrejas. E, além disso, não haveria, portanto, uma espécie quer de reocupação, quer de usurpação pelo Estado do antigo lugar ocupado pela religião nos processos de integração social (Blumenberg ou Löwith). E a segunda observação, de que com base nessa nova ênfase, Habermas reconheceria, sob um ponto de vista político, cidadania à religião na esfera pública: a secularização seria vista como transvalorização de conteúdos religiosos em critérios informadores dos debates públicos, uma vez traduzidos ao léxico secular, tendo assim sempre algo a dizer, mesmo àqueles que não compartilham de tais valores religiosos. $\mathrm{O}$ pano de fundo 
sobre o qual tal mudança de perspectiva fora empreendida por Habermas refletiria não apenas sua discussão com John Rawls acerca dos limites de uma reconciliação por meio de um uso público da razão ou mesmo suas interpretações em paralelo com as de Jacques Derrida sobre o 11 de setembro, mas também as posições que Habermas passou a assumir acerca de questões de bioética após os debates com Ronald Dworkin sobre o futuro da natureza humana, mas também, por fim, e em especial, seus posicionamentos quanto à ciência e à religião, sua teoria da adaptação e sua tese da sociedade pós-secular, nos debates com o então Cardeal Joseph Ratzinger.

Caberia indagar acerca de quais seriam as implicações para a arquitetura de uma Teoria Discursiva do Direito e do Estado Democrático de Direito, da nova tese segundo a qual viveríamos não mais uma era de política integralmente secularizada mas sim numa "sociedade pós-secular", especialmente quanto ao modo com que são enunciadas por Habermas em seu livro Entre naturalismo e religião, especialmente na introdução e no capítulo que se chama "Fundamentos pré-políticos do Estado Democrático de Direito?". $\mathrm{Se}$, segundo Habermas, vivemos numa época pós-secular, como ficaria a tese fundamental de Facticidade e Validade segundo a qual "não se pode ter nem manter um Estado de Direito sem democracia radical”, já que não mais viveríamos numa era da política totalmente secularizada? Isso implicaria reconhecer, então, fundamentos pré-políticos do Estado Democrático de Direito, no sentido de um aprendizado social recíproco entre seculares e religiosos, e o caráter inesgotável de intuições normativas ou de fontes de sentido às "grandes religiões mundiais", ou seja, que o processo democrático, para não dizer apenas uma Filosofia pós-metafísica, tem sempre muito o que ouvir e aprender com as religiões, ao mesmo tempo em que a Filosofia como observador externo nada teria a dizer?

Como nos lembra Marramao, em seu livro Céu e Terra (1997, p. 101), haveria pelo menos cinco acepções de secularização: 1) como ocaso da religião; 2) como conformidade ao mundo; 3) como dessacralização do mundo; 4) como descomprometimento da sociedade para com a religião; e 5) como transposição de crenças e modelos de comportamento da esfera religiosa para a secular.

Ao tema da secularização, portanto, ligam-se a questão da legitimidade da modernidade como legitimidade na modernidade, o problema da dinâmica moderna do tempo histórico, a questão da existência ou não de pressupostos pré-politicos de legitimidade do Estado Democrático de Direito, a questão da relação, enfim, entre religião e política, e entre elas e o Direito.

\section{3 - Reconstrução: por uma teoria constitucional reconstrutiva}

Menelick de Carvalho Netto (1998) nos chama a atenção para o modo como tradicionalmente as teorias jurídicas vão lidar com o problema da efetividade do Direito, com a questão do seu cumprimento e de sua aplicação efetivos. Essas teorias, que têm 
como exemplo a teoria constitucional de Loewenstein (1976) e sua classificação ontológica das constituições, afirmam em linhas gerais que o Direito representa um ideal de sociedade a ser perseguido, mas que, todavia, em face desses ideais normativos, a própria realidade poderia se apresentar como um obstáculo, a todo o momento, para que esse ideal pudesse ser realizado.

O problema desse enfoque é que, por um lado, desconhece que essa mesma realidade é também uma construção histórica e, por outro, que mesmo esse suposto ideal de uma nova sociedade que representaria o Direito surgiu na e, assim, faz parte da própria sociedade que o projeta. Ora, em última análise, tal enfoque revela-se uma postura reificada e reificante das identidades constitucionais que agrava ainda mais o problema que pretende denunciar, visto que acaba por contribuir para naturalizá-lo (CARVALHO NETTO, 2002, p. 46-52), ao contrário de procurar mostrar como é que os ideais de democracia e de justiça que pressupõem já estão inscritos, ainda que parcialmente, na realidade social, buscando resgatar criticamente e reconstruir, portanto, seus vestígios na própria história constitucional.

É preciso, pois, explorar as tensões presentes nas próprias práticas jurídicas cotidianas e reconstruir, de forma adequada ao Estado Democrático de Direito, os fragmentos de uma racionalidade normativa já presente e vigente nas próprias realidades sociais e políticas, pois é exatamente essa dimensão principiológica que inclusive torna passível de crítica uma realidade excludente (CATTONI DE OLIVEIRA, 2007b, p. 79. 84). Se esses ideais, como exigências de princípio, já não estivessem presentes, ainda que fragmentariamente, na própria história, a nos possibilitar a capacidade de reconhecer mesmo toda uma “catastrófica realidade social”, nós não seríamos também capazes nem mesmo de reconhecer as exigências normativas que o próprio projeto de construção e realização desses ideais nos coloca: sem uma vivência da exclusão, por um lado, e sem a pré-compreensão de um “constitucionalismo simbólico" (NEVES, 2006, 2007) daí decorrente, por outro, nem sequer os textos de normas constitucionais que se opõem à discriminação e a toda e qualquer forma de exclusão social teriam sido provavelmente incluídos, e de forma tão veemente, na Constituição da República de 1988.

Cabe lembrar com Muller (1998, p. 89) que a positivação jurídico-moderna como "textificação é faca de dois gumes", porque a Constituição pode ser tanto compreendida quanto desvirtuada no sentido de um "constitucionalismo simbólico", quanto também pode ser normativamente levada a sério. O texto da Constituição brasileira de 1988 não apenas fala de exclusão social, senão que se pronuncia incontestavelmente contra ela, como no caso dos textos de normas de direitos fundamentais, podendo revelar, portanto, diferentemente de um contraste entre ideal e real, uma tensão entre texto e contexto.

Numa leitura reconstrutiva, deve-se, portanto, virar o texto constitucional contra a exclusão social que, ao contrário de se ancorar numa lei natural, na verdade permanece 
historicamente vinculada aos pré-conceitos sociais não problematizados daqueles que vivenciam a Constituição. Aliás, como bem afirma Sorj:

"Muitos estudos de ciências sociais, no lugar de descobrirem as formas e sentidos de construção social da cidadania a partir dos próprios agentes sociais, refletem as frustrações da intelectualidade e das classes médias locais com suas próprias sociedades. Tal atitude, embora compreensível, alimenta uma tendência secular à desmoralização das instituições democráticas existentes, e as ciências sociais perdem a oportunidade de mostrar que a América Latina é um canteiro de experiências sociais que, com os cuidados devidos, indica problemas igualmente relevantes para os países capitalistas avançados" (SORJ, 2004, p. 20).

É exatamente nos termos de uma teoria constitucional comprometida com uma perspectiva reconstrutiva e atenta para os riscos de uma visão excessivamente normativa dos problemas de legitimidade/efetividade constitucional que proponho recolocar a pergunta acerca das histórias constitucional e política brasileiras e reconhecer, por exemplo, a importância do processo constituinte brasileiro de 1987-88, sobre o pano de fundo do constitucionalismo democrático.

Assim, pode-se afirmar que o processo constituinte de 1987-88 é um marco importantíssimo na história brasileira de um processo de constitucionalização (MARRAMAO, 2003, p. 228) que se reinicia antes mesmo do momento de promulgação do texto da Constituição e que se expressa tanto na tensão constitutiva entre desterritorialização e reterritorialização, presente em sua declaração de direitos e seus princípios fundamentais, quanto no caráter infuturante - histórico, polêmico e dinâmico, embora não relativo - desses direitos e princípios (MARRAMAO, 2008a, p. 170, e 2008b, p. 17-27). Numa leitura reconstrutiva, o processo constituinte de 1987-88 resgata, pois nele também se expressam, os princípios de autonomia e de emancipação das grandes revoluções do final do século XVIII - a liberdade, a igualdade e a fraternidade - sobre o pano de fundo da história política brasileira: ele, assim, se faz "herdeiro sem testamento" (ARENDT, 1990) de um processo de constitucionalização, perpassado por lutas por reconhecimento de atores e de direitos, que se desenvolve há pelo menos duzentos anos, todavia, de modo não linear, sujeito a tropeços e interrupções. Assim, cabe também resgatar nossa história política aqui e agora e relê-la no sentido da afirmação de princípio de que só em liberdade se garantem condições para o exercício da liberdade (MARRAMAO, 2003, p. 229). E, assim, contra o discurso da democracia possível, para além do reconhecimento da democracia inesperada, é que proponho a tese da democracia sem espera.

Uma teoria reconstrutiva da Constituição envolve, pelo menos, os seguintes pontos:

2.3.1) A pergunta central é como e não por quê: ou seja, de que modo, o Estado Democrático de Direito e a sua existência, e não qualquer outra forma de legitimação política, se tornaram não apenas possíveis mas exigíveis - e somente assim justificáveis - historicamente, assumindo-se a perspectiva do participante de um processo não linear 
e descontínuo de aprendizagem social com o Direito, que se desenvolve, ao longo do tempo, como construção dinâmica, polêmica, conflituosa e, portanto, rica e plural, de uma identidade constitucional democrática, não idêntica e não identitária, múltipla e aberta;

2.3.2) Romper com a perspectiva tradicional que compreende os problemas de legitimidade/efetividade a partir de uma dicotomia ou hiato entre um idealismo da Constituição e uma realidade social recalcitrante. Tal perspectiva agrava ainda mais o problema que pretende denunciar, e reifica a história constitucional, ao desconsiderar que a realidade é construída e não dada; nesta construção, as lutas jurídico-políticas por reconhecimento possuem um papel central;

2.3.3) Explorar as tensões presentes nas práticas sociais, políticas e jurídicas cotidianas e reconstruir os fragmentos de uma racionalidade normativa já presente e vigente nas realidades sociais e políticas, inclusive como critério crítico interno para esta realidade.

\section{DESAFIOS}

\subsection{Objetivo central}

Recapitulando, o objetivo central para uma história do processo de constitucionalização brasileiro é o de contribuir para uma reflexão acerca do sentido normativo que se autoexpressa na práxis de autodeterminação política no constitucionalismo, por meio de uma reconstrução acerca do modo como o processo de constitucionalização brasileiro articula memória e projeto, experiência e expectativa e, assim, deixa entrever as suas relações com o tempo histórico. Em outras palavras, busca-se demonstrar - por meio do desenvolvimento de uma concepção histórica e teorética que, incorporando as grandes contribuições da Teoria da História e da Filosofia contemporâneas, venha a romper com a perspectiva reificante da história constitucional brasileira vinculada à "tradição dos chamados retratos ou intérpretes do Brasil" - que as relações que a constitucionalização brasileira desenvolve com o tempo histórico podem ser compreendidas como processo não linear e descontínuo, reconstruído como processo de lutas por reconhecimento e de aprendizagem social com o Direito, que se realiza ao longo da história, todavia sujeito a interrupções e a tropeços, mas que também é capaz de se autocorrigir.

\subsection{Desafios específicos}

3.2.1) mostrar que um processo de constitucionalização não pode ser reduzido de forma historicista a um único "grande evento", em razão do caráter desterritorializante, insaturável e "infuturante" (MARRAMAO, 2008 a, p.169-189) - ou seja, polêmico, 
dinâmico, mas não relativo - dos princípios e direitos fundamentais que um texto constitucional interpreta;

3.2.2) mostrar que a constitucionalização é a expressão de "uma fundação como promessa" e, portanto, está sempre por-vir;

3.2.3) mostrar que a constitucionalização é processo não linear e, por vezes, descontínuo, de aprendizagem social, de abertura a um futuro-em-aberto, a um porvir (DERRIDA, 1992);

3.2.4) mostrar em que sentido a constituição democrática "não é uma utopia social e nem sequer é um substituto para esta idéia" (HABERMAS, 1998, p. 530);

3.2.5) mostrar que esta abertura recoloca a constitucionalização como tarefa permanente, e transmitida pelo passado, a cada nova geração - e, assim, os grandes eventos que marcam a sua descontinuidade e abertura poderão ser retrospectivamente recompostos como partes desse aprendizado histórico não linear, que representa a experiência da cidadania -, no exercício da autodeterminação jurídico-política e na defesa do patriotismo constitucional, sobre o pano de fundo de uma história mundial do constitucionalismo. E talvez esta seja a nossa maior herança do passado a ser resgatada, a responsabilidade no presente por um futuro-em-aberto, um porvir;

3.2.6) mostrar que o processo de constitucionalização é sempre "uma obra de reconstrução do navio em mar aberto" (MARRAMA0, 2003, p. 240), de um navio que já deixou o porto, que já navega pelo mar. Assim, num processo de constitucionalização, as exigências normativas que se colocam historicamente no interior desse processo constituinte - ou de constituição - que se realiza ao longo do tempo, ao contrário de barreiras a ele, são, na verdade, constitutivas dele: elas são uma forma de explicitação ou de autoexpressão da própria noção complexa de autonomia, que lhe é subjacente. Em outras palavras, todo processo de constitucionalização é um processo de autoconstitucionalização;

3.2.7) mostrar que a idéia do processo de constitucionalização como aprendizado social, tarefa cotidiana e permanente, exige romper com a teologia política, com esta máscara totêmica ou simulacro, de uma imagem icônica do sujeito-povo ou nação como totalidade homogênea - este phantasma da soberania, como diria Derrida (2008, p. 39). Um dos maiores problemas da democracia constitucional é ainda a obsessão pela falta, pela presença de uma ausência, de uma soberana una e indivisível, pela nostalgia do soberano deposto, morto ou exilado - que corre o risco, a todo momento, de ter o lugar reocupado de forma autoritária -, na perspectiva democrática de que tal processo de constitucionalização se desenvolve no tempo histórico como construção polêmica, conflituosa e, portanto, rica e plural de uma identidade constitucional múltipla e aberta;

3.2.8) mostrar que é no sentido de uma identidade constitucional não identitária e não idêntica construída ao longo do tempo, de uma identidade múltipla, aberta e, por 
isso, não mais passível de ser reificada, do(s) povo(s) como instância(s) plural(is), capaz de romper com a retórica da democracia possível e de seu autoritarismo instrumental, em direção a uma democracia sem espera (CATTONI DE OLIVEIRA in CATTONI DE OLIVEIRA e MACHADO, 2009, p. 367-399) - atenta para uma democracia por-vir (DERRIDA, 2003), para uma democracia compreendida como comunidade para-doxal, "como comunidade dos sem comunidade" e para um "universalismo da diferença" (MARRAMAO, 2003, p. 192) -, que podemos, mais uma vez, concordar com Habermas quando afirma que "no Estado Democrático de Direito, compreendido como a morada de uma comunidade jurídica que se organiza a si mesma, o lugar simbólico de uma soberania discursivamente fluidificada deve permanecer vazio" (1998, p. 529).

\section{UM POSGível PLANO DE TRABalHo}

Por fim, tendo em vista essa releitura tensa e complexa para uma nova história do processo de constitucionalização brasileiro que se busca realizar, é, por exemplo, possível adotar pelo menos sete eixos de pesquisa ou sete núcleos temáticos, a partir dos quais se poderia proceder a uma desconstrução, a uma crítica hermenêutica e a uma reconstrução de partes da história constitucional brasileira, de acordo com a justificação teórica apresentada:

$1^{\circ}$ eixo - $\mathrm{O}$ constitucionalismo imperial da Constituinte de 1823 à consolidação do Estado brasileiro no Segundo Reinado: o papel do Poder Moderador na formação da nacionalidade.

$2^{\circ}$ eixo - A crise do Império e a transição à República: os "bestializados" e a atuação política do Partido Republicano.

$3^{\circ}$ eixo - O constitucionalismo liberal de 1891 e suas contradições internas: a questão social como caso de polícia ou de políticas?

$4^{\circ}$ eixo - A Revolução de 1930 e seus desdobramentos. O Brasil sob Vargas, 1930-1954: o tema da integração nacional.

$5^{0}$ eixo - $\mathrm{O}$ constitucionalismo brasileiro do pós-guerra: história do conceito de populismo.

$6^{\circ}$ eixo - A autocracia militar de 1964-85: a tensão entre autocracia e Estado de Direito.

$7^{\circ}$ eixo - $\mathrm{O}$ processo de (re)democratização e o constitucionalismo democrático de 1988: projeto, perspectivas e desafios. 


\section{REFERÊNCIAS}

ABREU, João Capistrano de. Capítulos de história colonial e os caminhos antigos e o povoamento do Brasil. Brasília: Universidade de Brasília, 1982.

ALENCASTRO, Luís Felipe de (Org.). Império: a corte e a modernidade. São Paulo: Companhia das Letras, 1997.

ALVES, Maria Helena Moreira. Estado e oposição no Brasil. Bauru: EDUSC, 2005.

ANDRADE, Carlos Drummond de. Ausência. Disponível em: < http://www.lumiarte.com/ luardeoutono/drummond1.html\#7 > . Acessado em: 25/07/2009.

ARAÚJO, Valdei Lopes. A experiência do tempo: conceitos e narrativas na formação nacional brasileira (1813-1845). São Paulo: Aderaldo e Rothschild, 2008.

ARENDT, Hannah. The Human Condition. Chicago: University of Chicago, 1958.

ARENDT, Hannah. On Revolution. New York: Penguin,1963.

ARENDT, Hannah. Da revolução. Trad. Fernando Dídimo Vieira. São Paulo: Ática, 1990.

ARMITAGE, John. História do Brasil desde o período da chegada da família de Bragança em 1808 até a abdicação de D.Pedro I em 1831. Rio de Janeiro: Edições de Ouro, 1965.

BARACHO JUNIOR, José Alfredo de Oliveira. Dimensões paradoxais da jurisdição constitucional. In: CATTONI DE OLIVEIRA, Marcelo Andrade e MACHADO, Felipe Daniel Amorim (Orgs.). Constituição e Processo. Belo Horizonte: Del Rey, 2009, p. 153-167.

BARATA, Alexandre Mansur. Maçonaria, sociabilidade e Independência (Brasil, 1790-1822). 2000. Tese (Doutorado) - Unicamp, Campinas, 2000.

BARBOSA, Leonardo Augusto de Andrade. Mudança Constitucional, Autoritarismo e Democracia no Brasil pós-1964. Brasília: Programa de Pós-graduação em Direito (Tese de Doutorado).

BARRETO, Tobias. A questão do Poder Moderador e outros ensaios brasileiros. Petrópolis: Vozes, 1977.

BEINER, Ronald. Walter Benjamin's Philosophy of History. Political Theory, v. 12, n. 3, 1984, p. $423-434$.

BENJAMIN, Walter. Tesi di filosofia della storia. In: Angelus Novus: saggi e frammenti. Renato Solmi (Org.). Torino: Einaudi, 1995, p. 75-86.

BENJAMIN, Walter. Opere complete. VII Scritti 1938-1940. Rolf Tiedelmann e Herman Schweppnhäuser (Orgs.). Enrico Ganni (org. Trad. It.) Torino: Einaudi, 2006.

BERNARDES, Denis Mendonça. O patriotismo constitucional: Pernambuco, 1820-1822. 2002. Tese (Doutorado). USP, São Paulo, 2002.

BIGNOTTO, Newton. (Org.). Pensar a República. Belo Horizonte: Ed. UFMG, 2000.

BOMFIM, Manoel. O Brasil na História: deturpação das tradições, degradação política. Rio de Janeiro: Francisco Alves, 1930

BOMFIM, Manoel. O Brasil Nação: realidade da soberania brasileira. 2. ed. Rio de Janeiro: Topbooks, 1996.

BONAVIDES, Paulo e ANDRADE, Paes de. História constitucional do Brasil. Brasília: Paz e Terra, 1989. 
BORRADORI, Giovanna. La filosofia en una época de terror: diálogos con Jurgen Habermas y Jacques Derrida. Trad. Juan José Botero e Luis Eduardo Hoyos. Madrid: Taurus, 2003.

BOURGEOIS, Bernard. O pensamento político de Hegel. São Leopoldo: Unisinos, 2003.

BOURGEOIS, Bernard. Hegel: os atos do espírito. Sâo Leopoldo: Unisinos, 2004.

BRAUDEL, Ferdinand. Escritos sobre a história. Trad. Jacó Guinsburg e Tereza da Mota. 2.ed. São Paulo: Perspectiva, 2005.

BUENO, José Antônio Pimenta. Direito público brasileiro e análise da Constituição do Império. Brasília: Senado Federal, UnB, 1978.

CALMON, Pedro. História da civilização brasileira. 5. ed. aum. São Paulo: Comp. Ed. Nacional, 1945.

CALVET DE MAGALHÃES, Theresa. Ação, linguagem e poder: Uma releitura do capítulo V [Action] da obra The Human Condition. 2007. Disponível em: < http://www.fafich.ufmg. br/ tcalvet >. Acessado em: 26/07/2009.

CANDIDO, Antonio. Introdução. In: HOLANDA, Sérgio Buarque de. Raízes do Brasil. São Paulo: Companhia das Letras, 1995, p. 9-25.

CARDOSO, Fernando Henrique; FALETTO, Enzo. Dependência e desenvolvimento na América Latina: ensaio de interpretação sociológica. 7. ed. Rio de Janeiro: Zahar Editores, 1984.

CARVALHO, José Murilo de. A formação das almas: o imaginário da República. São Paulo: Companhia das Letras, 1990.

CARVALHO, José Murilo de. Caminhos da moral moderna: a experiência luso-brasileira. Rio de Janeiro: Itatiaia, 1995.

CARVALHO, José Murilo de. A construção da ordem/Teatro de sombras. Rio de Janeiro: Relume Dumará, 1996.

CARVAlHO, José Murilo de. Pontos e bordados. Escritos de história e política. Belo Horizonte: Editora UFMG, 1998.

CARVALHO, José Murilo de. Cidadania no Brasil: o longo caminho. Rio de Janeiro: Civilização Brasileira, 2001.

CARVALHO, José Murilo de. Os bestializados: o Rio de Janeiro e a República que não foi. São Paulo: Companhia das Letras, 1987.

CARVALHO NETTO, Menelick de. A sanção no procedimento legislativo. Belo Horizonte: Del Rey, 1992.

CARVALHO NETTO, Menelick de. A revisão constitucional e a cidadania: a legitimidade do poder constituinte que deu origem à Constituição da República Federativa do Brasil de 1988 e as potencialidades do poder revisional nela previsto. Revista do Ministério Público Estadual do Maranhão, n. ${ }^{\circ}$ 9, jan./dez. de 2002, p. 5-50.

CARVALHO NETTO, Menelick de. A hermenêutica constitucional e os desafios postos aos direitos fundamentais. In: SAMPAIO, José Adércio Leite (coord.). Jurisdição constitucional e direitos fundamentais. Belo Horizonte: Del Rey, 2003, p. 141-164.

CATTONI DE OLIVEIRA, Marcelo Andrade. Poder constituinte e patriotismo constitucional: O projeto constituinte do Estado Democrático de Direito na Teoria Discursiva de Jurgen Habermas. Belo Horizonte: Mandamentos, 2006. 
CATTONI DE OLIVEIRA, Marcelo Andrade. Direito, política e filosofia: Contribuições para uma teoria discursiva da constituição no marco do patriotismo constitucional. Rio de Janeiro: Lumen Juris, 2007.

CATTONI DE OLIVEIRA, Marcelo Andrade. Democracia sem espera e processo de constitucionalização: Uma crítica aos chamados discursos oficiais sobre a chamada "transição política brasileira". In: CATTONI DE OLIVEIRA, Marcelo Andrade e MACHADO, Felipe Daniel Amorim (Orgs.). Constituição e Processo: A resposta do constitucionalismo à banalização do terror. Belo Horizonte: Del Rey, 2009, p. 367-400.

CHRISTOFOLETTI, Rogério. O discurso da transição: Mudança, ruptura e permanência. Itajaí: Univali, 2000.

COMPARATO, Fábio Konder. Réquiem para uma Constituição. In: FIOCCA, Demian e GRAU, Eros Roberto. Debate sobre a Constituição de 1988. São Paulo: Paz e Terra, 2001, p.77-87.

COSTA, Maria Teresa. Il carattere distruttivo. Walter Benjamin e il pensiero della soglia. Roma: Quodlibet, 2008.

DERRIDA, Jacques. Séminaire: La bête et le souverain. Vol. 2 (2001-2002). Paris: Galilée, 2010.

DERRIDA, Jacques. Incondizionalità o sovranità. Trad. Simone Regazzoni. Milano: Mimesis, 2008a.

DERRIDA, Jacques. Séminaire: La bête et le souverain. Vol. 1 (2001-2002). Paris: Galilée, 2008b.

DERRIDA, Jacques. Force of Law: The "mystical foundation of authority". In: Drucilla Cornell (Org.). Deconstruction and the Possibility of Justice. New York: Routedge, 1992, p. 3-67.

DERRIDA, Jacques. História da mentira: prolegômenos. Trad. Jean Briant. Estudos avançados, v. 10, n. 27, 1996, p. 7-39.

DERRIDA, Jacques. Voyous: Deux essais sur la raison. Paris: Galilée, 2003a.

DERRIDA, Jacques. Stati canaglia. Trad. Laura Otello. Milano: Raffaello Cortina, 2003b.

DERRIDA, Jacques. ROUDINESCO, Elisabeth. De que Amanhã. Diálogo. Trad. André Telles. Rio de Janeiro: Jorge Zahar Editor, 2004.

DERRIDA, Jacques. Breve storia della menzogna: prolegomena. Roma: Alberto Castelvecchi, 2006.

DIAS, Claudete Maria Miranda. O outro lado da história: o processo de independência do Brasil, visto pelas lutas no Piauí - 1789-1850. 1999. Dissertação (Mestrado) - IFCS/UFRJ, Rio de Janeiro, 1999.

DWORKIN, Ronald. Law's empire. Cambridge, Mass.: Harvard University, 1986.

FAORO, Raymundo. A República inacabada. Org. Fábio Konder Comparato. São Paulo: Globo, 2007.

FAORO, Raymundo. Os donos do poder: formação do patriarcado político no Brasil. Rio de Janeiro: Globo, 2001.

FERRAZ JUNIOR, Tércio Sampaio. Constituinte: assembléia, processo, poder. 2 ed. São Paulo: Revista dos Tribunais, 1986.

FERREIRA FILHO, Manoel Gonçalves. A democracia possível. São Paulo: Saraiva, 1977a.

FERREIRA FILHO, Manoel Gonçalves. Sete vezes democracia. São Paulo: Saraiva, 1977b.

FERREIRA FILHO, Manoel Gonçalves. A reconstrução da democracia. São Paulo: Saraiva, 1979. 
FERREIRA FILHO, Manoel Gonçalves. O poder constituinte. 2. ed. São Paulo: Saraiva, 1985.

FERREIRA FILHO, Manoel Gonçalves. O anteprojeto dos notáveis. São Paulo: Saraiva, 1987.

FERREIRA FILHO, Manoel Gonçalves. A democracia no liminar do século XXI. São Paulo: Saraiva, 2001.

FERREIRA FILHO, Manoel Gonçalves. O poder constituinte. 5 ed. São Paulo: Saraiva, 2007.

FICO, Carlos. Além do golpe: versões e controvérsias sobre 1964 e a ditadura militar. Rio de Janeiro: Record, 2004.

FRANCO, Afonso Arinos de Melo. Estudos de direito constitucional. Rio de Janeiro: Revista Forense, 1957.

FRANCO, Afonso Arinos de Melo. Curso de direito constitucional brasileiro. 2. ed. Rio de Janeiro: 1968.

FRANCO SOBRINHO, Manoel de Oliveira. História breve do constitucionalismo no Brasil. 2a. ed. ampl. Curitiba: UFPR, 1970.

FERES JR., João e JASMIN, Marcelo Gantus (Org.). História dos Conceitos: Debates e Perspectivas. 1. ed. Rio de Janeiro: PUC-Rio; Edições Loyola; IUPERJ, 2006.

FERES JR., João e JASMIN, Marcelo Gantus (Org.). História dos Conceitos: Diálogos transatlânticos. 1. ed. Rio de Janeiro: PUC-Rio; Loyola; IUPERJ, 2007.

FREIRE, Gilberto. Casa-grande \& senzala. Rio de Janeiro: Record, 1998.

FUNARI, Pedro Paulo A. Considerações em torno das teses sobre filosofia da história, de Walter Benjamin. Crítica Marxista, n. 45. s/d, p. 45-53.

FURTADO, Celso. Formação econômica do Brasil. 34a. ed. São Paulo: Companhia das Letras, 2007.

GADAMER, Hans-Georg e KOSELLECK, Reinhart. Historia y hermenéutica. Trad. Faustino Oncina. Barcelona: Paidós, 1997.

GASPARI, Elio. A ditadura envergonhada. São Paulo: Companhia das Letras, 2001.

GASPARI, Elio. A ditadura escancarada. São Paulo: Companhia das Letras, 2002.

GASPARI, Elio. A ditadura derrotada. São Paulo: Companhia das Letras, 2003.

GIL, Antonio Carlos Amador. Projetos de Estado no Alvorecer do império: Sentinela da Liberdade e Typhis Pernambucano - a formulação de um projeto de construção do Estado. 1991. Dissertação (Mestrado). IFCS/UFRJ, Rio de Janeiro, 1991.

GOMES, Ângela de Castro. A república, a história e o IHGB. Belo Horizonte: Argumentum, 2009.

GRINBERG, Lucia. Partido ou bode expiatório: um estudo sobre a Aliança Renovadora Nacional (ARENA) 1965-1979. Rio de Janeiro: Mauad X, 2009.

GUIMARÃES, Samuel Pinheiro. Desafios brasileiros na era dos gigantes. Rio de Janeiro: Contraponto, 2005.

GUIMARÃES, Samuel Pinheiro. Quinhentos anos de periferia. Rio de Janeiro: Contraponto, 2007.

GUSTIN, Miracy Barbosa de Sousa e DIAS, Maria Tereza Fonseca. (Re)pensando a pesquisa jurídica. Belo Horizonte: Del Rey, 2010.

HABERMAS, Jurgen. El discurso filosófico de la modernidad. Trad. Manuel Jiménez Redondo. Madrid: Taurus, 1989. 
HABERMAS, Jurgen. Facticidad y Validez: Sobre el Derecho y el Estado Democrático de Derecho en términos de Teoría del Discurso. Trad. Manuel Jiménez Redondo. Madrid: Trotta, 1998.

HABERMAS, Jurgen. Constitutional democracy: a paradoxical union of contradictory principles? Political Theory, v. 29, n. 6, dec. 2001, p. 766-781.

HABERMAS, Jurgen. Tra scienza e fede. Trad. Mario Carpitella. Roma-Bari: Laterza, 2008.

HOLANDA, Sérgio Buarque de. Raízes do Brasil. São Paulo: Companhia das Letras, 1995.

HOLANDA, Sérgio Buarque de. História geral da civilização brasileira. São Paulo: Difel, 1970.

HOLANDA, Sérgio Buarque de. Visão do paraíso: os motivos edênicos no descobrimento e colonização do Brasil. São Paulo: Brasiliense, 1994.

HOMEM DE MELLO, Francisco Ignácio Marcondes. A constituinte perante a história. Ed. facsimilar. Brasília: Senado Federal, 1996.

HONNETH, Axel. Critica del potere: La teoria della società in Adorno, Foucault e Habermas. Trad. Maria Teresa Sciacca. Bari: Dédalo, 2002a.

HONNETH, Axel. Lotte per riconoscimento: proposte per un'etica del conflitto, Cidade: editora, 2002b.

HONNETH, Axel. La société du mépris: vers une nouvelle théorie critique. Paris: La découverte, 2006.

HONNETH, Axel. Reificazione: Un studio in chiave di teoria del riconoscimento. Trad. Carlo Sandrelli. Roma: Meltemi, 2007a.

HONNETH, Axel. Sofrimento de indeterminação: Uma reatualização da Filosofia do Direito de Hegel. Trad. Rurion Soares Melo. São Paulo: Singular/Esfera Pública, 2007b.

IGLÉSIAS, Francisco. História \& literatura: ensaios para uma história das ideias no Brasil. João Antonio de Paula (org.). São Paulo: Perspectiva; Belo Horizonte: Cedeplar-FACE-UFMG, 2009.

JANCSÓ, István (org.). Independência: história e historiografia. São Paulo: Hucitec: Fapesp, 2005.

JASMIN, Marcelo Gantus. Racionalidade e História na Teoria Política. Belo Horizonte: Editora UFMG, 1998.

JOBIM, Nelson Azevedo. A constituinte vista por dentro - vicissitudes, superação e efetividade de uma história real. In: SAMPAIO, José Adércio Leite (Org.). 15 anos de Constituição: história e vicissitudes. Belo Horizonte: Del Rey, 2004.

JÚNIOR, João Feres (Org.). Léxico da história dos conceitos políticos do Brasil. Belo Horizonte: Editora UFMG, 2009.

KELSEN, Hans. O conceito de Estado e a psicologia social. Com especial referência à teoria de grupo de Freud. In: KELSEN, Hans. A democracia. Trad.Ivone Castilho Benedetti e outros. São Paulo: Martins Fontes, 2000, p. 303-343.

KERVÉGAN, Jean-François. L'effectif et le rationnel. Hegel et l'Ésprit Objectif. Paris: Vrin, 2007.

KOSELLECK, Reinhart. Futuro passado: contribuição à semântica dos tempos históricos. Rio de Janeiro: Contraponto/PUC-RJ, 2006.

LABARRIERE; JARCZCK. Le syllogisme du pouvoir. Y a-t-il une démocratie hegelienne? Aubier, 1989.

LIMA, Manuel de Oliveira. D. João VI no Brasil (1808-1821). 2. ed. 3v. Rio de Janeiro: José Olympio, 1945. 
LUHMANN, Niklas. Sistemi sociali. Trad. Alberto Febrajjo. Bologna: Il Mulino, 1990.

LUSTOSA, Isabel. Insultos impressos: a guerra dos jornalistas na independência (1821-1823).

São Paulo: Companhia das Letras, 2000.

MALERBA, Joaquim (Org.). A independência brasileira: novas dimensões. Rio de Janeiro: Editora FGV, 2006.

MALLER, Marie-Louise (Org.). La démocracie à venir: Autour de Jacques Derrida. Paris: Galilée, 2004.

MARENCO, André. Devagar se vai ao longe? A transição para a democracia no Brasil em perspectiva comparada. In: MELO, Carlos Ranulfo e SÁEZ, Manuel Alcântara (Orgs.). A democracia brasileira: Balanço e perspectivas para o século 21. Belo Horizonte: UFMG, 2007, p. 73-105.

MARRAMAO, Giacomo. Poder e secularização: as categorias do tempo. São Paulo: UNESP, 1995.

MARRAMAO, Giacomo. Passaggio a occidente: Filosofia e globalizzazione. Torino: Bollati Boringhieri, 2003.

MARRAMAO, Giacomo. Minima temporalia: tempo, spazio, esperienza. Roma: Luca Sossela, 2005a.

MARRAMAO, Giacomo. Kairós: apologia del tempo debito. Roma-Bari: Laterza, 2005b.

MARRAMAO, Giacomo. Narrazione e contingenza (da un'intervista con Manuel Orazi) In: GUIDARNELI, Gianmario e MALACRINO, Carmelo G. (Orgs.). Storia e narrazione: retórica, memória, immagini. Milano: Bruno Mondadori, 2005, p. 21-24.

MARRAMAO, Giacomo. La passione del presente. Torino: Bollati Borinhieri, 2008a.

MARRAMAO, Giacomo. Pensare Babele. L'universale, il multiplo, la differenza. Iride, XXI, 52, gennaio/aprile de 2008b, p.17-27.

MARRAMAO, Giacomo. Hyperbolé. Politica, potere, potenza. Conferência realizada em Napoli, 2008c.

MARRAMAO, Giacomo. Messianism without delay: on the post-religious political theology of Walter Benjamin. Constellations, v. 15, n. 3, 2008d, p. 397-405.

MATTA, Roberto da. Carnavais, malandros e heróis. Rio de Janeiro, Zahar, 1981.

MATTA, Roberto da. O que faz o Brasil, Brasil? Rio de Janeiro: Rocco, 1999.

MELO, Evaldo Cabral de. A outra independência: o federalismo pernambucano de 1817 a 1824. São Paulo. Ed. 34, 2005.

MELO, Ciro Flávio de Castro Bandeira de. Senhores da história e do esquecimento: a construção do Brasil em dois manuais didáticos de história na segunda metade do século XIX. Belo Horizonte: Argumentum, 2008.

MONTEIRO, Pedro Meira; EUGÊNIO, João Kennedy (Orgs.). Sérgio Buarque de Holanda: perspectivas. Campinas: UNICAMP; Rio de Janeiro: UERJ, 2008.

MORAES, Vinícius de. Poética I. Disponível em: < http://www.viniciusdemoraes.com.br > Acessado em: 12/01/2009.

MONTEIRO, Tobias. História do império: a elaboração da independência. Rio de Janeiro: F. Briguiet, 1927.

MOREL, Marco. As transformações dos espaços públicos: imprensa, atores políticos e sociabilidades na Cidade Imperial (1820-1840). São Paulo: Hucitec, 2005. 
MOTA, Carlos Guilherme (Org.). Viagem incompleta:a experiência brasileira. Formação: histórias. São Paulo: SENAC, 2000.

MOTA, Carlos Guilherme. Viagem incompleta:a experiência brasileira. A grande transição. São Paulo: SENAC, 2000.

MULLER, Friedrich. Quem é o povo? Trad. Peter Naumann. São Paulo: Max Limonad, 1998.

NEUMANN, Franz L. The democratic and the authoritarian state. Essays in political and legal theory. Herbert Marcuse (Ed.). Glencoe: Free, 1957.

NEUMANN, Franz L. The change in fuction of law in modern society. In: NEUMANN, Franz L. e KIRCHHEIMER, Otto. The Rule of Law under siege. William E. Scheuerman (Ed.). Berkeley: University of Califórnia, 1996, p.101-141.

NEVES, Lúcia Maria Bastos Pereira das. Corcundas e constitucionais: a cultura e política da independência (1820-1822). Rio de Janeiro: Revan.: FAPERJ, 2003.

NEVES, Marcelo. Entre Têmis e Leviatã: uma relação difícil. São Paulo: Martins Fontes, 2006.

NEVES, Marcelo. A constitucionalização simbólica. 2. ed. São Paulo: Martins Fontes, 2007.

NOVAIS, Fernando Antônio; MOTA, Carlos Guilherme. A independência política do Brasil. 2. ed. São Paulo: Hucitec, 1996.

PAIM, Antonio. Introdução. In VIANNA, Francisco José de Oliveira. Populações Meridionais do Brasil. Brasília: Senado Federal, 2005, p. 19-45.

PAIXÃO, Cristiano e BARBOSA, Leonardo de Andrade. A memória da ditadura militar: a cláusula de exclusão da apreciação judicial observada como paradoxo. Revista do Instituto de Hermenêutica Jurídica, v. 1, n. 6, 2008, p. 57-78.

PAIXÃO, Cristiano e BARBOSA, Leonardo de Andrade. Cidadania, democracia e Constituição: o processo de convocação da Assembléia Nacional Constituinte de 1987-88. In PEREIRA, Flávio Henrique Unes e DIAS, Maria Tereza Fonseca (Org.). Cidadania e inclusão social: estudos em homenagem à professora Miracy Barbosa de Sousa Gustin. Belo Horizonte: Fórum, 2008, p. 121-132.

PAIXÃO, Cristiano. Entre passado e futuro: os desafios postos à afirmação dos direitos sociais e os 20 anos da Constituição da República. Inédito, 2008.

PAVONE, Claudio. Prima lezione di storia contemporânea. Roma-Bari: Laterza, 2007.

PEPERZAK, Adriaan T. Modern Freedom. Hegel's Legal, Moral and Political Philosophy. Dordrecht: Kluwer Academic, 2001.

PIPPIN, Robert. Hegel's Practical Philosophy: Rational Agency as Ethical Life. Cambridge: University of Cambridge, 2008.

PERETTI, Cristina de. Desconstrucción. In ORTIZ-OSÉS, Andrés e LANCEROS, Patxi (Org.). Diccionario de Hermenéutica. Bilbao: Universidad de Deusto, 1998, p. 143-149.

PRADO JUNIOR, Caio. Formação do Brasil contemporâneo. São Paulo: Brasiliese, 1969.

RAMOS, Saulo. Código da vida: Fantástico litígio judicial de uma família, drama, suspense, surpresas e mistério. São Paulo: Planeta, 2007.

REALE, Miguel. Da revolução à democracia. São Paulo: Convívio, 1977.

REIS, José Carlos. As identidades do Brasil: de Varnhagen a FHC. Rio de Janeiro: FGV, 2006a. 
REIS, José Carlos. As identidades do Brasil 2: De Calmon a Bonfim. A favor do Brasil: Direita ou esquerda? Rio de Janeiro: FGV, 2006b.

RICOEUR, Paul. La mémoire, l'histoire, l'oubli. Paris: Seuil, 2000.

RICOEUR, Paul. Parcours de la reconnaissance: Trois etudes. Paris: Gallimard, 2007.

ROCHA, João Cezar de Castro (Org.). Nenhum Brasil existe. Pequena enciclopédia. Rio de Janeiro: Topbooks/Univercidade, 2003.

RODRIGUES, José Honório. Aspirações Nacionais: interpretação histórico-política. 2. ed. São Paulo: Fulgor, 1965.

RODRIGUES, José Honório. Independência: revolução e contra-revolução. Rio de Janeiro: Francisco Alves, 1975.

ROSENFELD, Michel. A identidade do sujeito constitucional. Trad. Menelick de Carvalho Netto. Belo Horizonte: Mandamentos, 2003.

RUIZ, Castor Bartolomé (Org.). Justiça e memória: para uma crítica ética da violência. São Leopoldo: UNISINOS, 2009.

SANTOS, Wanderley Guilherme dos. Ordem burguesa e liberalismo político. São Paulo: Duas Cidades, 1978.

SANTOS, Wanderley Guilherme dos. O cálculo do conflito: estabilidade e crise na política brasileira. Belo Horizonte: UFMG; Riode Janeiro: IUPERJ, 2003.

SANTOS, Cecilia Mac Dowell; TELES, Edson; TELES, Janaina (Orgs.). Desarquivando a ditadura: memória e justiça no Brasil. Vol. II. São Paulo: HUCITEC, 2009.

SCHMITT, Carl. Théologie Politique, 1922, 1969. Trad. Jean-Louis Schlegel. Paris: Gallimard, 1988.

SCHOLEM, Gershom. Walter Benjamim e il suo angelo. Milano: Adelph, 2007.

SILVA, Francisco Carlos Teixeira da. Crise da ditadura e o processo de abertura política no Brasil. In: FERREIRA, Jorge e DELGADO, Lucília de Almeida Neves (Orgs.). O tempo da ditadura. Col. Brasil Republicano, v. 4. Rio de Janeiro: Civilização Brasileira, 2008, p. 243-282.

SILVA, José Afonso da. Poder constituinte e poder popular. São Paulo: Malheiros, 2000.

SOARES, Gláucio Ary Dillon; D’ARAÚJO, Maria Celina; CASTRO, Celso (Orgs.). A volta aos quartéis: a memória militar sobre a abertura. Riod e janeiro: Relume Dumará, 1995.

SOARES, Inês Virgínia Prado; KISHI, Sandra Akemi Shimada (Orgs.). Memória e verdade: A justiça de transição no Estado Democrático de Direito. Belo Horizonte: Fórum, 2009.

SODRÉ, Nélson Werneck. Formação histórica do Brasil. 13. ed. Rio de Janeiro: Bertrand Brasil, 1990.

SODRÉ, Nélson Werneck. Formação da sociedade brasileira. Rio de Janeiro: Livraria José Olympio Editora, 1944.

SORJ, Bernardo. A democracia inesperada: Cidadania, direitos humanos e desigualdade social. Rio de Janeiro: Jorge Zahar, 2004.

SOUZA, Jessé (Org.). A ralé brasileira: quem é e como vive. Belo Horizonte: UFMG, 2009.

VARNHAGEN, Francisco Adolfo. História da Independência do Brasil: até ao reconhecimento pela antiga metrópole, comprehendendo, separadamente, a dos successos occorridos em algumas províncias até essa data. Rio de Janeiro: Livraria Castilho, 1919. 
VARNHAGEN, Francisco Adolfo. História geral do Brasil: antes da sua separação e independência de Portugal. 8. ed. São Paulo: Melhoramentos, 1975.

VIANNA, Luiz Werneck. A revolução passiva: iberismo e americanismo no Brasil. Rio de Janeiro: Revan/IUPERJ, 1997.

VIANNA, Luiz Werneck. Travessia: da abertura à Constituinte. Rio de Janeiro: Taurus, 1986.

VIANNA, Oliveira. O idealismo da constituição. Rio de Janeiro: Terra de Sol, 1927.

VIANNA, Francisco José de Oliveira. Populações Meridionais do Brasil. Brasília: Senado Federal, 2005.

WILLIAMS, Robert. Hegel's ethics of recognition. Berkeley: University of California, 1997.

WOLKMER, Antonio Carlos. Fundamentos de História do Direito. Belo Horizonte: Del Rey, 2007.

WOLKMER, Antonio Carlos História do Direito no Brasil. Rio de Janeiro: Forense, 2009.

Recebido: setembro 2010

Aprovado: abril 2011 